\title{
COMPARATIVE BUSINESS NETWORKS IN EASTERN EUROPE ${ }^{1}$
}

\author{
Dr. Emanuela Todeva
}

\begin{abstract}
:
This paper represents a comparative analysis of seventeen case studies from Central and Eastern Europe, selected from different published sources. The analysis of these business cases is used to highlight the typical strategic responses of firms to the unstable business environment in the region. It is argued in the paper that the transition to market economy is accompanied by multiple business risks to firms, and these risks have obstructed the adjustment, re-positioning, and restructuring of firms and their business networks. Our selection of cases demonstrates the strategic attempts by firms to transform their relationships not only with buyers and suppliers, but also with foreign partners, financial institutions, and governmental bodies. As a result of our comparative analysis, a new typology of business networks is developed, including: transformed business networks, and newly established business networks.
\end{abstract}

Key words:

business networks; international business strategies in Eastern Europe; enterprise restructuring and adjustment; business environment in Central and Eastern Europe.

\section{INTRODUCTION}

The recent debates on privatisation and company restructuring in Central and Eastern Europe have been entirely dominated by the argument that privatisation is the only means for enterprise restructuring. Our secondary analysis of a number of published case studies aims to highlight a new dimension of the transition process, and to introduce the argument for the structural dependencies and barriers for change, usually underestimated in the academic literature. We analyse the factors reported in the cases that determine the company performance, and particularly those related to government policies, industrial linkages, and managerial strategies for survival in a turbulent environment.

The concept of 'business network' is used in this paper to describe the regular and repetitive transactions that an enterprise maintains with its suppliers and buyers within the value chain (see also Porter, 1991). The term 'network' includes the complexity of relations between companies, based on past contractual arrangements and present business links. The information on these linkages is rarely reported in the published cases. However, through a secondary analysis of the available information we highlight some of the main enterprise linkages, and their transformation under the new market conditions.

As a result of our comparative analysis, we have developed a classification of the cases in two main groups: a) 'transformed business networks' - comprising of cases of old firms that have gone through a period of significant changes, and that have successfully altered their position on the market, and their relationships with buyers and suppliers; and b) 'newly established business networks' - newly established companies that have radically changed their range of buyers and suppliers. In addition, the companies' linkages are classified into national and international networks, according to their access to markets.

The conceptual framework for the analysis of the adjustment behaviour of firms is based on a number of theoretical arguments: a) the role of the Central Plan in the design of

\footnotetext{
${ }^{1}$ In: The Journal of East-West Business, Vol. 6, N. 2, 2000, pp. 95-129.
} 
value chains; b) the role of the transition macro-economic environment, and its effect on firm's performance; and c) the effect of the withdrawal of the state on firm's strategies. The functioning of the Central Plan during the socialist period has established structural links between firms that have forced them into vertically and horizontally integrated production systems. These interlinked enterprises resemble business networks closely co-ordinated by the Central Plan. Some of the key mechanisms of this co-ordination are discussed in the following paragraphs.

The turbulence of the macro-economic environment during the transition period increased the business risk for individual firms. We give an overview in this paper of the sources of business risk, and the additional barriers on firms to restructure and reposition themselves on the market. The collaps of the Central Plan and the withdrawal of the state from control and regulation exposed firms to the intense market competition and increases their transaction costs. The strategic responses of the established firms illustrate typical behaviour in transition economies, and highlight the structural dependencies inherited from the central planning period.

\section{THE DESIGN OF BUSINESS NETWORKS BY THE CENTRAL PLAN}

One of the main functions of the Central Plan in the former socialist economies was to facilitate the transactions between firms. All of their inputs and outputs were pre-determined and inter-linked in a huge economic chain, driven by specified targets. The economic targets were measured by the 'planners' to satisfy broadly defined social needs. Therefore, under the Central Plan, there were no input or output markets, as firms were linked by the state administration to their input suppliers and output buyers.

All relationships of the individual firm in the past were pre-determined by administrative decisions. Kornai (1992) points out that fundamental decisions for the establishment of a firm, or its liquidation, for appointment, promotion and dismissal of managers, for the allocation of products, materials and labour, for price setting and financial regulation, for investment and technical development, for foreign trade and international economic relations - all were taken entirely by administrative bodies and individuals from the political and administrative elite. Needless to say that the Central Plan in this capacity reduced dramatically transaction costs for firms, and provided certainty for the realisation of their outputs.

The State Central Plan in the past was implemented through a number of intermediaries, responsible for the co-ordination and supervision of all economic activities of the firms. Some of the key 'insiders' therefore resided outside of the firm. After the collapse of the central planning system, the individuals working in these intermediaries were best positioned to take over the role of co-ordinating agents that are capable to manage the economic transactions between firms.

What might be called the nomenclature, or the individuals that comprise of the civil service and part of the 'political functionaries' of the socialist system, possessed the intimate knowledge for the allocation of resources within the economy (Willerton, 1992, Todeva, 1996). The nomenclature had the entire control of the information on economic transactions, market demand, differences in prices, and new business opportunities within the home market. They had also contacts with international business partners. It is not accidental that a large proportion of the early entrepreneurial activities were launched by the former nomenclature.

The intermediaries in the past, such as: Ministry of Planning, the State Council, The Council of Ministers and the Central Bank, served as buffers, absorbing shocks between the 
output from the state firms and the market demand. All of the intermediaries were involved in different stages of the design of the Central Plan, and the required subsequent alterations. With the collapse of the Central Plan, the functions of the intermediary institutions were disrupted, and the firms were exposed directly to the market. While state firms gained autonomy in this process, they also faced a resource dependency, under the conditions of uncertainty and lack of information. The resource dependency was due not only to the lack of financial capital, but also to the limited choice of suppliers that firms had inherited from the past, and from previous contractual relationships and obligations.

\section{THE TURBULANCE OF THE BUSINESS ENVIRONMENT DURING THE TRANSITION}

The collapse of the socialist system at the end of the eighties is most clearly associated with the failure of the administrative system and the Central Plan to co-ordinate efficiently the economic activities. The inability of the state to facilitate reliable transactions between firms, to provide incentives for innovation, to exercise control over dysfunctional managerial behaviour, and to obtain adequate feedback on policy implementation and the effectiveness of specific investment policies, was evident in each country of the eastern block.

The opening of the socialist economies to the global competition, and the subsequent collapse of the Central Plan, exposed firms to the uncertainties of the market. This was further exacerbate by the collapse of trade between the former $\mathrm{CMEA}^{1}$ countries, the drastic decline of the home market demand, the price liberalisation with the subsequent increase of costs of all inputs, the trade liberalisation, which increased foreign competition in almost all sectors of the economy, and the intensive tax reforms that further de-capitalised the firms.

The reduction of state intervention was an attempt to create autonomous economic entities, and to provide incentives for managers to establish new business links with buyers and suppliers as part of the restructuring.

Most of the Central and East European countries transformed large numbers of state firms into semi-autonomous corporations. The new corporatised form of state companies was expected to stimulate firms to establish independent business functions, previously coordinated by the Central Plan. Firms had to develop proper procurement and marketing functions, and this forced them to incur new transaction costs, previously absorbed by the state administrative bodies. The massive indebtedness between firms in Central and Eastern Europe could also be attributed to the previous lack of these business functions within state enterprises, along with the lack of adequate cost-accounting system. From being disigned, protected, and developed by Governments and bureaucrats under the central planning system, enterprises became overnight single autonomous units, exposed to the hostile macroeconomic environment.

The transition reforms overall effectively opened the door for individual interests to control the state owned firms, and unleashed the force of special group, professional, institutional and individual interests. These reforms in principle, served to re-locate power from government officials to new private intermediary organisations in the form of trade agents, that successfully replaced the functions of the Central Plan.

The new corporate governance structure included Boards of Directors and Management Boards. The composition of these bodies in some cases included individuals that provided state firms with access to resources and new markets. However, in the majority

\footnotetext{
1 CMEA - Council for Mutual Economic Assistance, facilitating trade between the member countries (Bulgaria, CSFR - Czechoslovak Federal Republic, GDR - German Democratic Republic , Poland, Hungary, the former USSR, Romania, associated members - Mongolia, Cuba, Vietnam, and observer - Yugoslavia).
} 
of cases, the Boards of Directors were ineffective to facilitate and to lead the strategic restructuring of the firms.

As a result of the corporatisation, a number of state control mechanisms over the economic activities of firms were lost. The most evident ones were the tax collection and the re-distribution of profits. The privatisation programmes in this respect have also failed so far to assure the establishment of effective control over the management of the enterprises, or in the majority of cases, to provide access to foreign capital and expertise, and to facilitate structural changes at macro level.

As Frydman and Rapaczynski (1994) point out, all the efforts to decentralise the economic system both before and after the collapse of the communist regimes, have not achieved their objectives. The macro-economic conditions, produced by transition policies, resemble a hostile and turbulent environment with extremely high inflation, negative economic growth, dramatic decline in demand and purchasing power, disco-ordination between regulatory bodies, and insufficient market information.

\section{SOURCES OF BUSINESS RISK IN TRANSITION ECONOMIES}

The intense transition reforms created macroeconomic instability that raised the risk of business operations throughout the whole region. The instability of the business environment exposed enterprises to multiple risks, such as: market risks, financial risks, and resource management risks (Ritchie and Marshal, 1993). The market risks, that firms faced, were determined mainly by the changes in demand, by the increased variations in consumer tastes and confidence, by the decline in individuals' purchasing power, and by the changes in government regulations.

The financial risks were determined by the instability of exchange rates (driven by the high inflation); by the increased taxation; by the level of bad debt, accumulated by individual firms; and by the withdrawal of state subsidies and relieves.

The resource management risks were induced by the unavailability of raw materials, qualified labour, and advanced technology.

If we look at the Government policies in Central and Eastern Europe from riskmanagement perspective, the liberalisation of trade and prices dramatically increased market risk. The shock therapies during the early transition in Poland and Bulgaria for example, had a much more dramatic impact on firms, compared with more gradual liberalisation policies in the Czech Republic and Romania. The liberalisation of prices is seen by managers in our cases as one of the major factors that led to massive increase of inter-enterprise debt, accumulated from non-receivables between buyers and suppliers. The monetarisation of the economy increased the financial problems and difficulties in obtaining credits, and blocked the payments between firms. The disrupted communications and trade relations (particularly with the collapse of the CMEA) led to multiple resource management risks. Suppliers from CMEA countries were usually obstructed by difficulties in intergovernmental negotiations of payments between member countries.

All these risks varied across industries and across countries, and this determined the different speed of the decline and recovery of different transition economies. For example, the Czech Republic was able to attract early foreign direct investment and to write-off the bad debts of a large number of state enterprises. This reduced the financial risks of these firms, and as we can see from the sellected case studies, the firms increased their chances for a successful adjustment to the new market conditions. 
This discussion leads to the conclusion that the risk aversive strategies adopted by the majority of firms in Central and Eastern Europe were the most appropriate response, as seen from the risk management perspective.

\section{STRUCTURAL DEPENDENCIES AND BARRIERS TO TRANSITION REFORMS}

Focusing on the enterprise response to transition reforms, it was expected that the privatisation and the liberalisation policies would automatically create an incentive structure and establish the pre-conditions for a rational economic behaviour. However, a detailed analysis of the business environment in transition economies suggests that the extreme level of uncertainty obstructs strategic decisions, and creates barriers for restructuring.

The official Government sources of information during the transition period were inadequate to provide reliable market information The lack of adequate market information puts an extra value on informal personal, professional, and political links and ties established by managers from the past. This explains why managers in Central and Eastern Europe enhanced their former links based on personal relations. These personal networks were employed in business to establish new contracts with suppliers and buyers, and to renegotiate managers' positions and the positions of their enterprises.

The positions of firms within the value chain, and their control over contracts with buyers and suppliers are discussed both in the strategy literature and the literature on networks. Although most of the research on network analysis is based on the definition of networks as the emergent structure from relationships between social entities (Wasserman and Faust, 1994), a number of research findings point out to other linkages between firms through ownership, and representation on Boards of Directors (Burt, 1979, Scott, 1987).

Our definition of business networks, as the repetitive transactions between firms, provides an additional perspective for the analysis of the dependencies between firms within their value chains. The dependencies on suppliers and markets exist also in developed market economies. However, the specific industrial structure in Central and Eastern Europe, inherited from the period of central planning, illustrates the structural dependencies that firms are facing. The concept of structural dependencies is particularly relevant in the context of high asset specificity and limited access to suppliers.

Most of the firms in the region were designed with high asset specificity, in order to serve a particular range of clients. The development of their business networks was driven by the output target (as fixed by the Central Plan, and required as a major input for another state firm). These material and product dependencies were coupled with locational distortions. Investments in manufacturing capabilities were located by the central planners according to social objectives for local economic development and for creation of employment in lessdeveloped regions.

One of the barriers to restructuring is that by design, firms were closely tied-up in buyer and supplier asset specificity. With the liberalisation reform and the subsequent increase of macro-economic instability and business risk, firms' strategic responses were driven by their existing linkages. The privatisation itself, unless it involved a foreign partner, did not facilitate enough the operational breaking of the former business networks.

In our analysis of the published case studies, we review different means used by firms to extend their choice of suppliers and buyers, and to increase their control over their value chain. Using Porter's framework for analysis of competitive advantage, we look at the way firms evaluate and respond to the power of suppliers and customers, and the way they protect themselves from substitutes and other rival products or services. The cases in our selection 
illustrate different aspects of the firms' relationships with buyers and suppliers. There is also information on diversification strategy, employed by the firms.

However, the responses to increased business risk are more clearly associated with the literature on market entry and motives for foreign direct investment. Amongst observed strategic responses are: the ingagement of foreign partners to assist in restructuring of the inherited business network of the firm, and the use of personal, professional and political networks in providing valuable market information and new contract opportunities.

In addition to the analysis of the strategic response of firms, we attempt to explain the restructuring of the business networks, looking at the effect of the macro-economic environment and other barriers, reported by managers in the case studies.

\section{METHODOLOGY FOR COMPARATIVE ANALYSIS AND CLASSIFICATION OF BUSINESS CASES}

The case studies used in this paper originate from a number of publications (Estrin, 1995, Hirschhausen and Hui, 1995, Johnson, et. al., 1996). The cases of firms from Bulgaria and Romania stem from unpublished research reports (Estrin, et.al., 1997), used in this paper with the permission of the authors. These case studies are treated as the main source of information for our secondary analysis.

Our underlying hypothesis is that the adjustment behaviour of firms during the transition is pre-determined by the macro-economic conditions, the position that each firm occupies in a particular industry, and its control over the value chain.

For analytical purposes seven new categories are developed to allow comparability between the cases and the companies from different countries. We interpret the effect of macro-economic environment as related to dependencies on government decisions. The information available on the industrial structure, relevant to each particular case, is interpreted as dependencies on intra-industry, inter-industry, and inter-firm linkages. Reported personal and professional linkages that affect business decisions are interpreted as personal, professional, and political networks. Information on firms' structure, organisation and capabilities is extracted from the published sources under the categories of intra-firm dependencies, and accumulated resources and capabilities / access to markets. In addition, the market conditions are described under the category uncertainty of resources. The strategic response of each particular company is described under the category strategic behaviour, adaptation, and repositioning.

These categories for the secondary analysis of the cases are defined in terms of the qualitative and quantitative information provided by the managers in each case, and stem from our analysis of the business risks and the structural dependencies in the region. The categories facilitate the analysis of the dependencies which each firm experiences in relation to its value chain, to its markets, and to Government policies.

The dependency of firms on government decision: The proper functioning of the market is a result of a systematic political process that involves government intervention through taxation, subsidies and regulations. The effect of government policies on company re-orientation during the transition period in Central and Eastern Europe is reported by managers mainly in reply to questions about barriers and difficulties experienced by the company.

Usually in their account managers refer to the effect of macro-economic policies such as: price and trade liberalisation, exchange rate adjustment and convertibility of the home currency, privatisation law and bankruptcy procedures, administrative and governmental decisions regarding company status and ownership structure, and other detailed aspects of the regulatory framework. In our analysis we look at the barriers to restructuring and 
development, imposed on firms by Government regulations and the effect of protectionist government policies.

The dependency of firms on inter-firm, inter- and intra-industry linkages: The socialist industrial system was built with a high degree of integration of processes and operations across different industrial sectors of the economy in order to achieve economies of scale. The management control and the strategic skills for the co-ordination of the vertical and the horizontal linkages were located in State Industrial Holding Companies and Branch Ministries (Kornai, 1992, Chavance, 1992, Todeva, 1997). Therefore, there was a designed market structure, which influenced intra-industry mobility of resources, directed by the State Holding Companies (called Industrial Associations and Combines). There were effectively no new market entryes of new businesses. All input and output markets (determining the value chain and the value system of individual enterprises (Porter, 1991)) were pre-designed by the administrative authorities, and facilitated repetitive transactions. Managers usually reported information relevant to this category when asked about the difficulties with suppliers, difficulties with the distribution of their products, changes of customers, and relationships with administrative organisations and financial institutions.

Personal, Professional and Political Networks: It is an established fact that the former socialist economies were managed by highly hierarchical political and administrative structures, that represented the totalitarian state. After the collapse of the Central Plan, many of these relationships were transformed into personal networks and informal groupings of individuals, that continued to work with each other. Usually this information is provided by managers who describe personal links that are used for their business. These professional and political networks resemble very much the patronage relations described by Willerton (1992).

Intra-firm dependencies: This category refers to the work by Mintzberg (1983) on intra- and inter-organisational power relationships and structures for decision making and control. This includes the structure of corporate control. Managers reported in the cases the difficulties they face in the areas of: departmental structure, business functions, industrial relations, and the entire internal environment of the company. These characteristics are called intra-firm dependencies. They usually are perceived by managers as barriers to organisational change and business restructuring.

The Accumulation of Resources and Capabilities / Access to Markets: The published case studies provide information about the size of the firm, production capacity, product range and differentiation, or any other strengths that give comparative advantage to the company itself. The market access is included in this category as well, because in principle it secures revenue for the firm. These strategic advantages we have labelled as accumulated resources and capabilities. In our analysis we compare how these resources are used for strategic restructuring and re-positioning of the firm.

Uncertainty of Resources: This category facilitates the collection of information about barriers, and market threats. Usually managers reported problems they have to solve, including: changes in their market demand, and the lack of particular resources (due to market deficiencies).

Strategic Behaviour: All cases in our selection have addressed the issue of the changes made (or attempted) during the transition period. The reported information includes both intended and implemented changes, or any attempts that the firm has made for adaptation, re-orientation, and re-positioning on the market.

All these categories are indicative, and they serve mainly the purpose to provide a comparable framework for interpretation of the published cases. Our secondary analysis provides a profile for each company, whith emphasis on firms' dependencies and responses to the business risks. This additional interpretation and review of the published information 
facilitates a better understanding of the transition processes that affect the company behaviour.

Our comparative analysis of the cases identified two main criteria that determine the type of strategic response of the firms: a) structural dependency of the firm; and b) market dependency. According to these criteria we devided all cases in the following groups: a) business networks based on transformed dependencies, comprising of firms established under the old system of Central Planning, and b) newly established business networks, evolved along new business start-ups, or the appropriation of the business operations by new legal entities such as joint ventures, or acquisitions. Each group is divided into two sub-groups referring to national business networks, and international business networks, according to their main market and access to foreign partner. The grouping of international business networks includes firms engaged in economic transactions with foreign partners, and refers to the modes of foreign market entry of international firms by Stephen Young (1989). Young's categories include: a) exporting, b) licensing, c) franchising, d) management contracts, e) turnkey contracts (for establishment of a complete production unit or infrastructure project), f) international subcontracting (or placing orders with specifications), g) industrial cooperation agreements (involving government agencies), h) contractual joint ventures, j) equity joint ventures, $\mathrm{k}$ ) wholly owned subsidiaries. If firms report only repetitive transactions with partners within the home market, their business networks are treated as national.

\section{TYPOLOGY OF BUSINESS NETWORKS}

The first group of cases (Table 1.) represents firms with long history that have successfully transformed their dependencies within the business network of suppliers, buyers, and other contract agencies. The measure of success here derives from the managerial evaluation of the firm's performance, and from our evaluation of the strategic responce, as described in each case. The assumption is that the withdrawal of the state and the collapse of the Central Plan, has required firms to replace the mechanisms of allocation of resources. In doing so firms have repositioned themselves within the value chain. Ultimately, non-successful firms are those, that have terminated their work, with frozen assets and operations, or firms that have faced bankruptcy.

TABLE 1: Business Networks Based on Transformed Dependencies

\begin{tabular}{|c|c|}
\hline \multicolumn{2}{|l|}{ National Business Networks } \\
\hline & 1. LITHUANIA - Industrial Holding Co. in Electronics \\
\hline & 2. HUNGARY - Hungartextile Holding / Textile / Cloth \\
\hline \multicolumn{2}{|l|}{ International Business Networks through: } \\
\hline shared ownership & 3. LATVIA - PAF Minibus Assembling \\
\hline industrial cross-border co-operation & $\begin{array}{l}\text { 4. CZECH REPUBLIC - PSP - Heavy Engineering / Iron } \\
\text { Processing Machinery }\end{array}$ \\
\hline licensing \& exporting & 5. CZECH REPUBLIC - Spolana / Chemicals \\
\hline Exporting & $\begin{array}{l}\text { 6. ROMANIA - Clujana Trading Co. / Leather \& Leather } \\
\text { Substitute Shoes }\end{array}$ \\
\hline subcontracting \& exporting & $\begin{array}{l}\text { 7. CZECH REPUBLIC - Motorpal / Auto Parts, Fuel } \\
\text { Injection }\end{array}$ \\
\hline
\end{tabular}




\section{LITHUANIA - Industrial Holding Co. in Electronics ${ }^{2}$}

The Lithuanian case of a Holding company in the electronics industry demonstrates how a highly centralised and capital intensive business network from the past has transformed itself into a private Holding company with effective control over the entire industrial sector of Lithuanian electronics.

There is no information about the internationalisation of the electronics industry as a consequence of this restructuring, and this is the reason why this case is placed in the subgroup of national business networks. The authors of the case argue that the entire process has been driven by the rapid privatisation in the country. The inconsistency of government policies related to privatisation issues, has allowed a highly organised professional network of 'managers' within the electronics sector to take control of the majority of assets. The mechanism of consolidating the former network has been facilitated by the privatization program of the Lithuanian Government.

\section{Dependency on Government Decisions:}

... Most Investment Funds were established in 1992 with no regulatory framework on the composition of assets or price, and no competition control; Creation of multiple funds by the same people; In 1992, the professional group of managers in the electronics established the EBSW Investment Fund ...

\section{Inter-Industry dependencies:}

... In 1992 EBSW Investment Fund bought 40\% of the shares of TV-2, 30\% - of TV-1; in addition managers acquired directly another 25\% of TV-2 shares and 30\% of TV-1 shares; $5 \%$ of the Investment Funds in Lithuania hold 52\% of the invested vouchers in the electronic sector; each investment fund controls a commercial bank, one or more insurance companies, a distribution network and trade firms; in this way, an investment fund with the smallest possible amount of capital have become the majority owner of a large network of enterprises...

The case does not provide sufficient information whether this transformation of ownership has led to changes in efficiency, or even in profitability. However, it demonstrates how the main group of the largest two manufacturers in the electronics sector, and seven of their major suppliers, have formed a Holding company as an extended business network, comprising of an investment fund, a commercial bank, at least one insurance company, a distribution network, and a number of trade firms.

This case demonstrates that the restructuring of the electronics industry in Lithuania is not a market led transformation. A professional network of individuals have transformed the entire sector of the electronics industry, re-enforcing previously existing inter-industry linkages and dependencies on suppliers and markets. They have used the dependencies on centralised Government subsidies and the regulatory reforms in Lithuania as a vehicle for achieving their private aims.

It is also evident from the case, that the new business formation is lobbying the Government to conclude new commercial agreements with the CIS countries, in order to facilitate access to the Russian markets for the private holding company.

\footnotetext{
${ }^{2}$ Hirschhausen, C. \& Hui, W. (1995) Industrial Restructuring in the Baltic Countries: Large-scale Privatisation, New Enterprise Networks and Growing Diversity of Corporate Governance, In: Communist Economies \& Economic Transformation, Vol. 7, No. 4, pp. 421-443.
} 


\section{HUNGARY - Hungartextile Holding / Textile / Cloth $^{3}$}

The second example in the group of transformed national networks is Hungartextile Holding, which controls $30 \%$ of the total output of the Hungarian textile / cloth industry.

\section{Dependency on Government Decisions:}

... The 1988 Act on Economic Associations transformed the former Economic Associations into Holdings with independent subsidiaries; The intention of creating the Holdings was to create an assets management structure, which will perform many administrative functions including some from the subsidiaries ...

\section{Intra-Firm Dependencies:}

... It was established as a Holding in June 1989; In 1991 the subsidiaries became loss-makers themselves; From March 1992, it was supervised by the Government through State Property Agency; The Holding lost all of its production, but kept part of its predecessor's purchasing and sales functions; Cross-ownership between subsidiaries, while the Holding controls between $80-98 \%$ of the shares in each subsidiary...

This case shows in contrast with the Lithuanian Electronics, that the actual ambitions of the managers are not to run the holding company, but to use it as a legal entity that bears the liabilities of the loss making firms. The expectations are that these loss-making firms will be closed by the Government to clear the bad debts.

The devolution of administrative control in Hungary has changed the ownership status of the members of the Hungartextile Holding. However, the case does not suggest a major change in the suppliers and buyers networks of the main firm. The change of ownership and the formation of the Holding company has not led to a diversification of products, or to access to new markets. On the contrary, the case shows that in spite of the significant changes in the structure of ownership and control, the loss of CMEA markets (43\% of their output in 1991) has made all of the subsidiaries of the Holding into loss making firms.

The high level of technology (60-70\% up to western standard) has created overcapacity which poses additional questions for a rationalisation of the business. The changes in ownership have not altered the dependency of the firm both on the Government decisions, and on the structure of the textile / cloth industry, and the intra-firm linkages between subsidiaries. This case is also an example of the fact that the interests linked to the privatisation are focused on the high value-added business functions.

Both cases of the Lithuanian Industrial Holding in Electronics and the Hungarian Hungartextile Holding demonstrate 'successful' change of ownership from an economic perspective. However, the brief review of these cases highlights the barriers to their repositioning on the international market.

There are a number of published cases of firms that were able to internationalise their activity. This type of transformed business networks is presented in the separate sub-group of international business networks.

\section{LATVIA - PAF Minibus Assembling ${ }^{4}$}

An interesting case of internationalisation of the business network through shared cross-border ownership is the Latvian company PAF, operating in the sector of minibus assembling. From the original case it is evident that the Latvian company in the past has been

\footnotetext{
${ }^{3}$ Estrin, S., et al. (Eds.) (1995) Restructuring and Privatisation in Central Eastern Europe: Case Studies of Firms in Transition, M. E. Sharp, Inc., New York.

${ }^{4}$ Hirschhausen, C. \& Hui, W. (1995) Industrial Restructuring in the Baltic Countries: Large-scale Privatisation, New Enterprise Networks and Growing Diversity of Corporate Governance, In: Communist Economies \& Economic Transformation, Vol. 7, No. 4, pp. 421-443.
} 
heavily dependent on Russian suppliers and the Russian market. This has forced the company management and the Latvian Government to initiate in 1995 a cross-ownership deal with the Russian company GAZ - their strategic supplier.

\section{Dependency on Government Decisions:}

... 78\% of privatisations in Latvia have been carried out through long-term lease ...

\section{Inter-Industry Dependency:}

... The company PAF is a centre of a large network of 10 major and 100 minor suppliers of materials and components; $10 \%$ of the suppliers are from Latvia, and $80 \%$ - from the FSU, and the most strategic one is GAZ; At least three of its major Russian suppliers decided to start minibus production themselves (GAZ, Bratsk, Uliyanov) ...

\section{Accumulated Resources and Capabilities / Access to Markets:}

... The company was a supplier of minibuses to the entire SU; until 1992 - the only producer in FSU of 12seat passenger and ambulance vans; 93\% of its production distributed in the FSU...

The internationalisation of ownership, and the re-enforcement of the former dependencies, within the production chain has helped the company to maintain its position on the Russian market. The case shows that the main factor that drives the successful transition of the firm is its access to markets, rather than the change of ownership. The change of ownership in this case is motivated by the attempt to tie-up GAZ who is the main supplier of parts and a potential competitor. This is a defensive strategy by PAF, which has high specificity of its assets, and aims to protect its position in a business network that is located in Russia.

\section{CZECH REPUBLIC - PSP - Heavy Engineering / Iron Processing Machinery ${ }^{5}$}

The Czech company PSP Heavy Engineering is a very good example of how an influential management team in this sector, and an appropriately selected Board of Directors and Supervisory Board, have succeeded in lobbying the Czech Government for a number of favourable decisions. This is an example of Young's type of international market entry through industrial cross-border co-operation involving the governments of The Czech Republic and Ukraine.

\section{Dependency on Government Decisions:}

... In the past the company was supported by Government orders through a state foreign trade firm, which subcontracted work for a large multi-governmental investment project in Ukraine and Russia through an Investment Engineering Group; The state provided long-term, low-interest, government guaranteed bank loans; The state foreign trade firm used to bare all risks; In 1988, the Investment Engineering Group split into several parts, and The Principal Contractor unit became a division in PSP; In 1993 the outgoing Czechoslovak Government agreed to stop its investment in Ukraine, to pay the loan collateral and the interest payments in yearly instalments for 10 years and to pay PSP lost profits; The Government transferred ownership of the assets to all major suppliers to the project and one potential buyer of the products from the Ukrainian venture (all newly privatised) ...

\section{Accumulated Resources / Access to Markets:}

... Most overdue receivables were recovered and the irretrievable ones were sold; The company used the unclear relationships on the multi-governmental investment project in Ukraine as a secure market, utilising the cheaper loan and completing its part of the investment; Produces technological equipment for coal power stations, cement and ceramic industries; Its main clients at present are privatised construction companies; The firm plans to grow in a niche market of environmental technology...

\footnotetext{
${ }^{5}$ Estrin, S., et al. (Eds.) (1995) Restructuring and Privatisation in Central Eastern Europe: Case Studies of Firms in Transition, M. E. Sharp, Inc., New York.
} 
The case shows that the firm has survived through 'extracting' financial resources from the Czech Government in a variety of ways, rather than through re-positioning itself on the market. This includes the clearance of the bad debts of the firm.

This case shows how through its political network, the company has turned its dependency on the Ukrainian market, and the inter-government negotiations of crossownership into an advantage, by sheltering itself from the shocks of inflation and the unfavourable exchange rates.

\section{CZECH REPUBLIC - Spolana / Chemicals ${ }^{6}$}

Another Czech company in the heavy chemicals industry Spolana demonstrates the point that without a major transformation of ownership, or changes in its relationship with suppliers, the company has survived through increased exports to western markets, and through the internationalisation of its business network.

\section{Dependency on Government Decisions: \\ ...Cancellation of debt in 1991 by the Government; Dependent on cheap crude oil from Russia and a range of imports ...}

\section{Accumulation of Resources and Capabilities/ Access to Markets:}

... Size-10,000; 17\% reduction of the labour force; Highly diversified production in industrial chemistry, man-made fibres, plastics, agrochemistry, gastrochemistry, synthetic hormones for the medicine ...

\section{Strategic Response:}

...Significant proportion of their products are made under the license of foreign firms; $R \& D$ cooperation with University for Chemical Technology in Prague; 55\% of exports are to Germany \& Benelux countries; The loss of domestic markets was compensated by rapid growth in exports; Obtained credits were secured by immovable assets exceeding 1.3 times the credit ...

The main form of internationalisation for Spolana is licensing and exporting. However, the successful restructuring of the firm was supported by the government cancellation of firm's debt in 1991, which enabled it to obtain fresh credits.

\section{ROMANIA - Clujana Trading Co. / Leather \& Leather Substitute Shoes ${ }^{7}$}

The Romanian company Clujana in the footwear industry is an example of a firm that has expanded its national business network and simultaneously has increased its international presence through exports. Within its national business network, it has linked itself with two new ownership funds - the State Property Fund, and the Private Property Fund called IV Muntenia. This has enabled it to secure financial resources from both of them. It could be argued that the major change for the company is the shift of control - from ministerial control to control by the two ownership funds, who also facilitate its access to foreign markets.

\section{Inter-Industry Dependency:}

...High degree of production integration - the company has the capacity to ensure all necessary semiproducts for its own use and for other shoe producers...

\footnotetext{
${ }^{6}$ Estrin, S., et al. (Eds.) (1995) Restructuring and Privatisation in Central Eastern Europe: Case Studies of Firms in Transition, M. E. Sharp, Inc., New York.

${ }^{7}$ Estrin, S., et al. (Eds.) (1997) [Case Study Reports in Bulgaria and Romania], ACE-PHARE Research Project No. 910381-R.
} 


\section{Strategic Behaviour:}

...Decrease of production for sales on domestic market from 63.7\% (in 1991) to 50.5\% (in 1994) and a forecast of 33\% (by 1998); Increased production for foreign markets from 36\% (in 1991) to 49.5\% (in 1994) and was forecasted 67\% (by 1998); Planning re-technologisation of the factories with the support from the State Ownership Fund ...

This is an example of a successful linkage between the production firm Clujana with financial institutions which also manage its exporting activities and the overall internationalisation.

\section{CZECH REPUBLIC - Motorpal / Auto Parts, Fuel Injection ${ }^{8}$}

The Czech company Motorpal operates in the automotive industry, producing auto parts and fuel injection. In comparison with the other cases, they are one of the largest firms and one of the most experienced in conducting international business operations. However, their survival has been determined not so much by the managerial competencies in restructuring and adjustment, but by their almost monopolistic position in the sector, their technical expertise and know-how, their intensive capitalisation by the former socialist governments, and their business ties with the car manufacturer Skoda, through which they have gained access to new business partners in Germany.

In spite of the fact that the managers do not report specific business linkages, it is evident that in addition to the reputation of a former CMEA market leader, the company has benefited from subcontracting to Skoda's acquirers, Volkswagen. It is clear in this case that the main revenue of the company at present comes from their exporting and subcontracting activities. The case describes well different attempts for restructuring.

\section{Uncertainty of Resources:}

...The collapse of CMEA market and the decline in the domestic market led to 60\% cut in orders; Delayed payments by clients caused secondary indebtedness and shortage of cash...

\section{Dependency on Government Decisions:}

...In 1990 became a joint stock company; The two major changes that affected trade were 1990 currency devaluation through changes in exchange rates and 1991 price liberalisation; As part of the macroeconomic stabilisation wages were frozen for the first half of 1991 and remained regulated until the end of 1992, which led to social unrest in the firm; The government cancelled part of the debts of the firm and the debt of many of its suppliers and customers, but the banks applied this credit to the interest, not to the loans of the firms ...

\section{Accumulated Resources:}

...The company comprises of seven plants in six towns - 3,800 employees...

\section{Intra-Industry Dependency:}

...Active participation of fuel injection producers in $R \& D$ with engine producers ...

\section{Strategic Behaviour:}

... In 1991-92 two new products were produced for the West European market, which is a proof of good technical skills; Exploring new markets in Middle East, North Africa, India, Indonesia \& China ...

\footnotetext{
${ }^{8}$ Estrin, S., et al. (Eds.) (1995) Restructuring and Privatisation in Central Eastern Europe: Case Studies of Firms in Transition, M. E. Sharp, Inc., New York.
} 
Under the category of newly established business networks (Table 2.) we have grouped firms that have appeared on the market as new business start-ups, or new legal entities, that do not bare directly the liabilities of former state enterprises.

TABLE 2: New Established Business Networks

\begin{tabular}{|c|c|}
\hline \multicolumn{2}{|l|}{ National Business Networks } \\
\hline & 1. CZECH REPUBLIC - Tipa / Footwear Industry \\
\hline \multicolumn{2}{|c|}{ International Business Networks through: } \\
\hline contractual joint venture & 2. HUNGARY - Elegant Charm / Textile / Garments \\
\hline equity joint venture & $\begin{array}{l}\text { 3. HUNGARY - Interchokolade KFT / Food Processing / } \\
\text { Chocolate }\end{array}$ \\
\hline equity joint venture & $\begin{array}{l}\text { 4. SLOVAK REPUBLIC - CS-07 / Food processing / Chocolates } \\
\text { \& Sweets }\end{array}$ \\
\hline subcontracting & 5. POLAND - Szczecin Shipyard / Shipbuilding \\
\hline exporting & 6. ESTONIA - Tarmenco / Furniture Industry \\
\hline exporting & 7. BULGARIA - P-05 / Textile / Cloth \\
\hline
\end{tabular}

\section{CZECH REPUBLIC - Tipa / Footwear Industry ${ }^{9}$}

Of interest is the Czech company working in the footwear industry, named Tipa. It is unclear why the company has been classified by its managers as operating in the footwear sector as it is actually involved in businesses in ten different industrial sectors, including agricultural production, travel services, construction (also export of labour in construction), agricultural machinery sales, foreign trade, shoe production, frozen food and ice-cream production and sale, a bakery for bread production, general retail and wholesale, a real estate agency services, and telecommunication and security services. As some of the facilities were acquired from former state firms, the link with the Government has been strong.

\section{Dependency on Government Decisions:}

...A general lack of money in the economy meant that other resources were blocked as accounts receivable after their maturity; To offset the burden of taxes the firm received subsidies in 1991...

\section{Personal, Professional and Political Networks:}

...The group of the nine founders of the business are former executives from nearby state and co-operative farms in the area of Trade, Travel, Information, Production, and Agriculture, and they knew each other for many years from the High School ...

\section{Accumulation of Resources and Capabilities / Access to Market:}

...Size - 600 employees in 10 industrial sectors; Accumulation of different technologies \& contacts which allowed diversification; Rely on their own information of the market opportunities and the available skills; Maintain a rich network of contacts and connections which facilitates business operations such as: finding sources of inputs, leasing offices and work spaces, and identifying high profit market niches and take-over opportunities...

\section{Strategic Behaviour:}

...It is constructing a plant for wood processing with second hand machinery from a bankrupt Swiss cooperative; All investments have been made using loans or leasing service; Planning joint ventures with German and Italian partners and a joint venture with a Russian partner to facilitate barter deals; Exporting labour to Germany; Planning to expand into a milk processing plant, an acquisition of a packaging plant and establishment of a regional savings bank; Planning to expand in Slovakia by acquiring some

\footnotetext{
${ }^{9}$ Estrin, S., et al. (Eds.) (1995) Restructuring and Privatisation in Central Eastern Europe: Case Studies of Firms in Transition, M. E. Sharp, Inc., New York.
} 
businesses in a particular town - looking for businesses with high profit margin; Registered two investment funds for the privatisation and trained the managers of the funds; Operating within regional boundaries ...

It has started as a small business start-up in the retail sector with a regional focus of operations. The company has grown rapidly through an intense diversification, and has achieved high profit margins in all activities as identified by their well informed managerial team. At the centre of this business network stands a group of nine former executives from local state and co-operative farms who have known each other for many years. It seems that the business has grown around the personal ties that each individual has maintained from the past.

\section{HUNGARY - Elegant Charm / Textile / Garments ${ }^{10}$}

Very similar in this respect is the case from the Hungarian textile industry Elegant Charm Ltd. It is a spin-off of a major industrial group of ten plants, which has managed to survive through a co-operative agreement with Levi Strauss. This is an example of a business network that demonstrates both the efforts of Central and East European firms to access western markets, and the interests of the western partners to expand eastwards in this highly labour intensive industrial sector.

\section{Intra-Firm Dependencies:}

...The company was established in 1990 as a spin-off from the main Group of ten plants; Some of these plants had obsolete technology and become financially a drain on the firm; Initially the largest shareholder was the main group - with 48,9\% share, equivalent to the machinery and equipment arbitrarily overpriced; The second shareholder was OTP Bank with $25.5 \%$ and three smaller private firms (a small trading house, an agricultural co-operative \& a small private firm) with $25.6 \%$ combined; Later on, the equity stakes of the three smaller firms were sold to a single private firm; The present Director General has been the former head of trade \& co-operation department at the old Group, who initially disagreed of splitting the Group; Lack of marketing department and as a result of that the company is loosing 4-5\% added to the final sale price dealing through trading houses...

\section{Intra-Industry Dependency:}

...There is a large number of firms on the domestic market which compete with imports rather than between themselves; The intensity of competition is caused by the narrow specialisation of producers and their direct access to the retail market, therefore the retail firms design their network of suppliers ...

\section{Uncertainty of Resources:}

...The company is under-capitalised due to its small collateral, necessary for credits; The domestic market for finished products had shrunk due to fall in household consumption; The Group utilised only small part of the capacity of the company and this created need to find new markets outside the orbit of the Group; Uncertainty of ownership - some of the small share holders were liquidated, others sold their shares and the Group was also in liquidation ...

\section{Strategic Behaviour:}

...The firm has a co-operation agreement with Levi Strauss for jeans; There is a signed agreement between the two firms that the company can not enter into business relations with a Group's partners for 5 years; Produces leather clothing, which is capital intensive and takes a lot of firm's profit for re-financing routine short term credits; A deep gap between production \& marketing capabilities \& lack of co-ordination between the two; Aggressive subcontracting to utilise up to $108 \%$ of the capacity; Gradually creating an independent design department, which made of up to 15\% of the sales; Gradually closing down several loss-making product lines, such as leather clothing and fur products; These capacities were converted to textile-sewing; The management would like to acquire the shares owned by the Group after the Group's liquidation - at a price of 75\% of their value, offering to take $50 \%$ of them and the other $50 \%$ to offer to the

\footnotetext{
${ }^{10}$ Estrin, S., et al. (Eds.) (1995) Restructuring and Privatisation in Central Eastern Europe: Case Studies of Firms in Transition, M. E. Sharp, Inc., New York.
} 
workers; The management also has started negotiations to acquire the shares from OTP Bank; Planning a take-over one of the plants of the Group, or to purchase the facilities rented rat present...

The internationalisation of the company is achieved through the contractual joint venture with Levi Strauss and through exporting (as much as $60 \%$ of its output is exported). However, the company itself has no marketing or sales department, and this demonstrates its dependency not only on the international partner, but also on the trading houses that operate as intermediaries in its business dealings.

\title{
HUNGARY - Interchokolade KFT / Food Processing / Chocolate ${ }^{11}$
}

The Hungarian company Interchokolade KFT in the food processing industry has been gradually acquired by a Swiss multinational company 'Globalfood'. This acquisition obviously brings international expertise and market opportunities for one of the four largest Hungarian manufacturers in this sector. However, in this case it is suggested that by joining the international network of Globalfood subsidiaries, the company has lost autonomy, and has become a dependent division which provides manufacturing facilities and access to the Hungarian market for the Swiss multinational firm.

\begin{abstract}
Dependency on Government Decisions:
...Nationalised in 1947, integrated into an industrial trust in 1963 \& decentralised in 1981 when it was forced to merge with a sugar factory until 1985; This led to depletion of company's reserves due to world crisis and depressed prices for the sugar industry; Taxes on profits were not paid in 1991 due to extremely high taxes on wages introduced with the new income tax system in 1988; Received export subsidies until 1990 and the company experienced a significant decline in export performance after; The Swiss partner 'Globalfood', became an almost exclusive owner in 1992...
\end{abstract}

\section{Intra-Industry Dependency:}

...The Hungarian confectionery industry was highly competitive since 1987 with 4 state enterprises, 37 bakery firms owned by municipalities, and 30 co-operatives; By 1991 the industry was dominated by three firms which were ranked 19, 32 \& 98 on the Hungarian industry list of the top 200 firms; Exogenous factors have quite a strong impact, because price fluctuations on the sugar market are large and this affects profits...

\section{Uncertainty of Resources:}

...Total increase of costs between 1988-91 - 77\%, including 138\% wage costs, $142 \%$ fixed costs, 43\%materials \& 62\%-energy; Rapid increase of wages without significant lay offs; 10 times increase of bank debt (1988-91) due to higher interest rates, inflation and delayed payments; Irredeemability of most receivables which doubled between 1990-91 and increased more than 10 times after 1988; The firm lost completely its autonomy and was integrated into the world confectionery industry in exchange of its access to the Hungarian domestic market for chocolate products...

In spite of the privatisation of KFT by a Multinational company, the main advantages for the Hungarian firm seem to be the maintained core labour force, and the stable financial situation of the firm.

\section{SLOVAK REPUBLIC - CS-07 / Food processing / Chocolates \& Sweets ${ }^{12}$}

The Slovak company 'CS-07'has agreed an equity joint venture with Jacobs-Suchard, after $27 \%$ of the labour force was sacked. Of note here is that the interest of the foreign

\footnotetext{
${ }^{11}$ Estrin, S., et al. (Eds.) (1995) Restructuring and Privatisation in Central Eastern Europe: Case Studies of Firms in Transition, M. E. Sharp, Inc., New York.

${ }^{12}$ Estrin, S., et al. (Eds.) (1995) Restructuring and Privatisation in Central Eastern Europe: Case Studies of Firms in Transition, M. E. Sharp, Inc., New York.
} 
company was instigated primarily by the presence of their international competitors (Nestle and BSN/France) in the Czech Republic.

\section{Dependency on Government Decisions:}

...The legal system provides weak penalties for not fulfilling a contract; The Ministry of Agriculture and Grocery had no power to manage the firm with exception of appointing the General Director and evaluating the economic results annually; In 1992 the firm became a Joint-Stock Co., administered by the Fund of National Property who appoints the Board of Directors (a General Director and four ViceDirectors) and the Supervisory Board (with one representative from The Fund and two from the firm)...

\section{Intra-Industry Dependency:}

...In the past $80 \%$ of production was purchased by wholesale organisations; Their collapse led to increase of inventories; The firm now access the market only through small businesses...

\section{Uncertainty of Resources:}

...Above 70\% of exports were to CMEA markets; The collapse of the system for integrative sales in 1990 led to discoordination of production and sales (in a situation when demand exceeds the supply) and the need for planning by the firm ...

\section{Strategic Behaviour:}

...It has agreed a sale of 32\% of the shares to the Swiss firm (Jacobs-Suchard), which is to increase to 66\% through future investment; At present it subcontracts to a German company against delivery of technology $\&$ ingredients; Obsolete products and packaging were replaced by purchase of packaging materials from Austria, Germany \& Italy; Most recent strategies include diversification of production and discontinuity of some product lines; Planned full merger with Jacobs-Suchard, build-up of new distribution channels through new domestic and foreign partners, acquisition of technology, and expansion into the former CMEA markets...

This shows that the expansion of international business networks in Central and Eastern Europe should be considered more as driven by the wider global competitive environment, rather than by competitive advantages within the region, such as new business opportunities that derive from the regulatory reforms in each country, or enterprise competitiveness.

\section{POLAND - Szczecin Shipyard / Shipbuilding ${ }^{13}$}

An exemplary case of internationalisation of an old business network is the shipyard in Szczecin. It has emerged from a deeper crises than its neighbour the shipyard in Gdansk, and had outplayed it. This is due to a number of factors, including: the aggressive marketing strategy, adopted by its Chief Executive, addressing a world niche market in medium size containers; the internal re-organisation of the production line; the introduced new remuneration system; and the shedding of non-productive assets.

\section{Dependency on Government Decisions:}

...The new managing director secured co-operation of the Polish Development Bank (PDB), a Government bank designed to assist in large scale enterprise restructuring; The firm was administered in the past by Industrial Shipbuilding Union, directly accountable to the Ministry of Industry; Governments used to locate clients \& negotiate with customers through the state trade company 'Centromor' - for a $2 \%$ commission of a ship's selling prise; The Government provided all finance for a new ship construction, which included subsidies for unprofitable projects (often up to $50 \%$ of the total construction cost)...

Intra-Firm Dependency:

\footnotetext{
${ }^{13}$ Johnson, S. et.al. (1996) Complementarities and the Managerial Challenges of State Enterprise Restructuring: Evidence from Two Shipyards, In: Economics of Transition, Vol. 4, No. 1, pp. 31-42. (Only the two cases in Shipbuilding industry in Poland)
} 
...In 1991 the yard and the Polish Development Bank created a joint venture 'Container Ship' with 50\% ownership each; The PDB operated as a guarantee for fleet owners' prepayments and to provide working capital...

\section{Accumulation of Resources and Capabilities / Access to Markets:}

...Major customers in the past were Eastern Bloc countries, particularly FSU; The trading company paid the yard in domestic currency upon completion of a project; In 1988 signed a contract for four container ships for German ship owners and the first one being delivered in 1991; In 1992 signed contracts with German fleet owners for another 13 container ships worth $\$ 300 \mathrm{mln}$; Total contracted ships for 1992 were 48 , or $40 \%$ of the international market for medium size containers...

\section{Strategic Behaviour:}

...By 1991 had \$150 mln debt because of expensive bank loans and Soviet insolvency; It was forced to delay payments to over 1500 suppliers and a number of commercial banks; Created a new marketing office in 1989 to pursue clients and to identify a niche world market; Reduced labour force from a peak of 13,000 (in 1970s) to 6,000 (in 1991); In 1992 the production value was $\$ 182 \mathrm{mln}$ and required 5,000 workers; Aimed to narrow its product focus and to develop a niche market - for container ships particularly in medium class; Closed two out of six slipways and a number of other departments comprising 1500 workers which were transferred to the main production line; Reduced product cycle time for a single ship from 2-4 years to 11 months; Changed remuneration from paid in piece rate per task to hourly wages adjusted by qualification category; Reversed the compensation hierarchy and put highly qualified workers on top; No overtime work was permitted; The new average salary was two times the national average; Eliminated many of the employee amenities; Developed competitive advantage by focusing the production; Increased productivity by reducing the production cycle, by the implementation of performance enhancing compensation scheme, by the shedding of non-productive assets, and by the reduction of the number of employees directly involved in ship assembly...

It also could be argued that the success of Szczecin shipyard, at the time of the case study, is due not only to the strategic restructuring efforts of its management team, but also to the business relationships it has established with the Polish Development Bank, and the new joint venture between the two partners with a stake of $50 \%$ equity each. In fact, this new access to financial resources we consider as growth of the business network of the old shipyard, which reduces the dependency of the firm on externally secured bank loans.

However, the most important elements of the business network are the contracts with German ship owners, that provide the firm with an access to important new customers and secure revenue. The numerous contracts with the German ship owners, that the firm has acquired, could also be attributed to the former personal and professional contacts and business links, as well as the expertise in negotiations of their Chief Executive. This case is an example of a successful transformation of the firm's business network both nationally, through an equity joint venture with a financial institution as a new legal entity, and internationally, through subcontracting in a niche market.

\section{ESTONIA - Tarmenco / Furniture Industry ${ }^{14}$}

The case of the Estonian firm Tarmenco in the furniture industry, is also an example of a successful internationalisation, switching from the former Russian and CMEA markets to the western markets. The export activities are organised through joining international distribution and sales networks.

\footnotetext{
${ }^{14}$ Hirschhausen, C. \& Hui, W. (1995) Industrial Restructuring in the Baltic Countries: Large-scale Privatisation, New Enterprise Networks and Growing Diversity of Corporate Governance, In: Communist Economies \& Economic Transformation, Vol. 7, No. 4, pp. 421-443.
} 


\section{Intra-Industry Dependency:}

...The privatization led to almost instantaneous reorganisation of production structures and networks in industries close to final demand and less capital intensive like the furniture industry; Upstream, the supply of wood and other inputs from Soviet sources was largely cut off and had to be replaced with payments for supplies in hard currency; Downstream, the entire distribution system collapsed...

\section{Accumulation of Resources and Capabilities / Market Access:}

...In 1991, 96\% of the production was for FSU, while in 1993 88\% of the products were sold in western countries ...

\section{Strategic Behaviour:}

...The survival strategy includes: to diversify production (from 5 - to 150), to develop new products, and to hook up to existing distribution and sales networks in the west; in 1994 six directors of the enterprise took over two-thirds of the property...

\section{BULGARIA - P-05 / Textile / Cloth $^{15}$}

The Bulgarian company P-05 also has developed a network of new customers, but mainly national trading companies, that manage on their behalf the export of $80 \%$ of the entire production, and $20 \%$ of the imported inputs of the company.

\section{Dependency on Government Decisions:}

...In 1991 the enterprise was transformed into a public limited company under the supervision of the Ministry of Industry; A main burden is the rise in energy prices and the decline in domestic demand, rather than the competition from imports; The devaluation of the currency had a positive effect on the firm ...

\section{Accumulation of Resources and Capabilities / Access to Markets:}

...Compared to 1990, the volume of production in the sector decreased by $46 \%$ in 1993; The firm holds $40 \%$ of the national woollen yarn market and $25 \%$ of the worsted cloth market; A presence of a lot of new contractors since the start of the reform; Size in 1994 - 2,000 employees; The volume of production is growing and in 1994 the demand exceeded the supply...

\section{Strategic Behaviour:}

...The company has access to new international markets and new resources and bigger independence in setting prices; It has diversified production as a result of its own design projects; It has created a network of customers which provides opportunities for exports of $80 \%$ of its production; Investment in new technology is not a priority for the managers and the firm could maintain its market position on the basis of present equipment and by putting in operation non-utilised reserves ...

In principle, some of the companies in this group represent more transformed business networks, rather than newly established ones. However, we have placed these cases in this group to assert the argument that in the cases of successfully restructured companies, there is a clear brake in the structural linkages within their value chain. P-05 and Tarmenco have changed radically their suppliers and buyers, and operate now in completely new markets. Szczecin Shipyard and CS-07 have entered a joint venture which allows them not only access to new resources, but also change of buyers and markets.

The acquisition of Interchokolade has changed its legal identity and its business operations, while Tipa and Elegant Charm are examples of the entrepreneurial skills of former managers, who have pulled out assets from former state firms and have started new ventures.

\footnotetext{
${ }^{15}$ Estrin, S., et al. (Eds.) (1997) [Case Study Reports in Bulgaria and Romania], ACE-PHARE Research Project No. 910381-R.
} 


\section{CONCLUSIONS}

Risk management in Central and Eastern Europe is a feature of the transition period which has not attracted enough attention in the academic literature. The dominant assumption is the 'inadequacy' of managers to respond to the 'new' market signals delivered through macro-economic policies. The 'irrational' economic behaviour of the managers is usually attributed to limited knowledge, experience, and the so caled 'post-communist' culture. In this way it overlooks the role of structural factors in the business environment.

The research on Central and Eastern Europe identifies a list of contradictory objectives that companies had to pursue in relation to enterprise restructuring: 1) Managers had to develop new business functions (particularly marketing and sales) and therefore bringing in new staff, while simultaneously they had to reduce the labour force; 2) Managers had to reduce costs, while at the same time they had to diversify into new products and markets, requiring additional investments; 3) They had to increase internal financial accountability within the firm under a dramatic decline in available working capital, which forced them to use alternative and 'risky' methods of payment; 4) They also had to reduce the labour force, while some of the methods for mass privatisation suggested a strong interest of keeping it intact. If we add to this picture the time and resource constraints that managers from the region experienced, one could understand why managerial decisions were not always adequate to the complexity of the situation. The dependency on past experience and networks was also reinforced by the need to secure scarce and expensive resources, and to engage in some contracts that would ensure the survival of the firm.

The cases included in this analysis aim to demonstrate the wide variety of business networks and co-operative relations that have evolved during the transition period in Central and Eastern Europe. Some of the cases show that firms have consolidated former dependencies, designed by the central planning system. However, the variety of responses by firms indicated the ability of the managers to find new niche markets for survival, and new opportunities for internationalisation.

The firms included in our analysis show that, inspite of the general similarities at industry level, Central and East European companies are not homogeneous by history and current business strategy. The differences in transformation of structural linkages, formerly established by the Central Plan, is seen as being driven mainly by external to the enterprise forces. These external factors derive from the instability of the business environment in the region, from the collapse of the CMEA market and the depression of the home market in each country, and from the structural dependencies within the economy due to mis-allocation of resources by the Central Plan.

The result of the restructuring strategies produces two groups of behaviour transformed business networks, and newly established networks. The companies that have transformed their former dependencies into manageable business networks show their ability to control the external environment primarily through lobbying governments (PSP Heavy Engineering), and through influencing the regulatory framework for privatization (Lithuanian Industrial Holding in Electronics).

For most of the companies in this group, the transition policies have not affected their dominant position in their industries, in spite of the collapse of the market demand (Spolana, Motorpal). Their strategic response overall has been to consolidate further their position in the value system (PAF, Hungartextile Holding). The former industrial linkages of the firms, and the personal and professional relationships maintained by their Chief Executives, have determined both the positive and the negative outcomes of their adjustment.

The companies with established new business networks demonstrate examples of blurred firms' boundaries (Tipa), of increased dependency on the national and foreign trade 
firms, or on international partners in joint ventures and acquisitions (Tarmenco, P-05), and in subcontracting to foreign firms (Interchocolade, CS-07, Elegant Charm).

The lack of a marketing function by the former socialist enterprises has been one of the most evident reasons for the managers' failure to adapt to the drop in demand. Most of the cases show that an access to new markets facilitates company restructuring. This suggests that the discussions on value chains and the extent to which companies control the elements of the entire value system are critical and important in explaining many of the difficulties in enterprise restructuring experienced in Central and Eastern Europe.

Further analysis is required to establish a more detailed classification of the cooperative business networks that have evolved in Central and Eastern Europe during the transition period. Additional analysis could also reveal new patterns of adaptive company behaviour, and their variations across industries, regions and countries.

\section{REFERENCES}

Burt, R. (1979) “A Structural Theory of Interlocking Corporate Directorates”, Social Networks, Vol. 1, pp. 415-435.

Chavance, B. (1992) The Transformation of Communist Systems. Economic Reform Since the 1950s, Westview Press, Oxford.

Dewatripont, M. \& Roland, G. (1996) Transition as a Process of Large-scale Institutional Change, In: Economics of Transition, Vol. 4, No. 1, pp. 1-30.

Dobrinsky, R. (1996) Enterprise Restructuring \& Adjustment in the Transition to Market Economy: Lessons from the Experience of Central and Eastern Europe, In: Economics of Transition, Vol. 4, No. 2, pp. 389-410.

Estrin, S., et al. (Eds.) (1995) Restructuring and Privatisation in Central Eastern Europe: Case Studies of Firms in Transition, M. E. Sharp, Inc., New York.

Estrin, S., et al. (Eds.) (1997) [Case Study Reports in Bulgaria and Romania], ACE-PHARE Research Project No. 91-0381-R.

Frydman, R. \& Rapaczynski, A. (1994) Privatisation in Eastern Europe: Is The State Withering Away? Central European University Press, London.

Hirschhausen, C. \& Hui, W. (1995) Industrial Restructuring in the Baltic Countries: Largescale Privatisation, New Enterprise Networks and Growing Diversity of Corporate Governance, In: Communist Economies \& Economic Transformation, Vol. 7, No. 4, pp. 421-443.

Johnson, S. et.al. (1996) Complementarities and the Managerial Challenges of State Enterprise Restructuring: Evidence from Two Shipyards, In: Economics of Transition, Vol. 4, No. 1, pp. 31-42.

Kornai, J. (1992) The Socialist System: The Political Economy of Socialism, Clarendon Press, Oxford.

Marinov, Marin et. al. (1998) ' Privatization and Company Restructuring in Eastern Europe', In: Journal of East-West Business, vol. 4, N. 1/2, pp. 29-46.

Meyer, Klaus (1998) 'Enterprise Transformation and Foreign Investment in Eastern Europe', In: Journal of East-West Business, vol. 4, N. 1/2, pp. 7-28.

Mizruchi, M. \& Schwartz, M. (Eds.) (1987) Intercorporate Relations. The Structural Analysis of Business. Cambridge University Press, New York.

Nohria, N. \& Eccles, R. (Eds.) (1992) Networks and Organisations: Structure, Form, and Action. Harvard Business School Press, Boston, Massachusetts.

Pfeffer, J. (1987) A Resource Dependence Perspective on Intercorporate Relations, In: Intercorporate Relations. The Structural Analysis of Business. Cambridge University Press, New York. 
Popov, Vladimir (1998) 'Investment in Transition Economies: Factors of Change and Implications for Performance’, In: Journal of East-West Business, vol. 4, N. 1/2, pp. 47-98.

Porter, M. (1991) “Towards a Dynamic Theory of Strategy”, In: Strategic Management Journal, Vol. 12, pp. 95-117.

Ritchie, B. \& Marshall, D. (1993) Business Risk Management. Chapman \& Hall, London.

Scott, J. (1987) "Intercorporate Structures in Western Europe: A Comparative Historical Analysis”, In: Intercorporate Relations: The Structural Analysis of Business, Mizruchi, M., \& Schwartz, M. (Eds.), Cambridge University Press, N.Y., pp. 208232.

Todeva, E. (1996) Dynamics of Management Practices in Eastern Europe: The Case of Bulgaria, In: Journal for East European Management Studies, No. 4, pp. 47-70.

Todeva, E. (1997) Co-operative Business Strategies in Eastern Europe. paper presented at the 4th International Conference on Multi-Organisational Partnerships \& Co-operative Strategies, 8-10 July 1997, School of Management Studies, University of Oxford.

Willerton, J. (1992) Patronage and Politics in the USSR. Cambridge University Press, New York.

Young, S. et. al. (1989) International Market Entry and Development, Harvester Wheatsheaf, Hertfordshire: UK. 